\title{
CONSTANTINOPLE AS A CENTRE OF ISLAM
}

For illustrations of the tendency of history to repeat itself go to Constantinople. Its story during a thousand years is a story of the Christian religion and of the Empire that grew strong as representing Christianity. It is a story of how the imperial city fostered not only hopes beyond the clutch of calamity, but also misuse of opportunity and wanton degradation through luxury, and then offered the surprise of manly resistance to furious enemies and of fortitude that endured through irremediable disaster. We cannot dwell upon this part of its history, although we Westerners are so fixed at our own point of view that we may often forget the long prosperity of this city as capital of the Roman Empire when the Western Empire was a mass of fragments trodden under the feet of barbarians. What we have to survey is the importance of Constantinople to Islam. Here the story of the city in outline is a mere repetition of the unassailable hopes of the Christian period and all the rest-the misuse of opportunity and the manly defence when all Europe has gnashed its teeth over it in a very madness of hate. The city has not yet prepared the final catastrophe for its Mohammedan owners, but we may see tokens that it is leading up to disaster for Islam even as it did for the Eastern Christian Church.

Mohammed's entire sincerity in declaring that he was called of God to undertake the reform of the world will always be doubted. Yet one has to admit that his steadfast determination to possess Constantinople, the impregnable, counts in favour of his strong belief that God was on his side. Immediately after gaining control of the Arab tribes about Mecca and Medina he announced and prepared to execute this audacious scheme. Death smote him before he had time for more than a demon- 
stration towards the Roman frontier. But he passed on to his followers as a sacred legacy the duty of taking Constantinople that Islam might be enthroned on the ruins of Christendom. That God had promised and would give the city to Islam was to be believed as a dogma of the faith. During one hundred and forty-four years-that is to say, until the year 798-the Arabs strove to perform the duty laid upon them. Their perseverance in the face of immeasurable obstacles might be compared to that revealed by a century of national failures to reach the North Pole. How highly they rated the importance of that peerless city appears in the patience with which they seven times renewed its siege, sometimes spending three or four or more years in exhausting attack. By the end of the eighth century all of Western Asia knew that any cost in treasure and in blood would be as thistle-down when weighed against the possession by Islam of a city so renowned and so invincible. Nevertheless, the Arabs saw no fulfilment of the promise of their prophet.

Six hundred years passed away before Constantinople was again besieged. Meanwhile the Turks had become warriors for the Prophet, had overrun the Roman territories in Asia, had crossed into Eastern Europe, and had discovered that military and political reasons made the immunity of the imperial city intolerable. Troops and fleets directed from Constantinople had crushed sooner or later many attempts of Asiatics to break away from its dominion. From the Adriatic and the Danube to Persia, Armenia, Syria, Egypt and the deserts of Arabia, the Roman emperors of Constantinople had made their power a terror to any who took up arms without leave. The voice of Constantinople weighed in all political schemes and ambitions. In religious matters, too, Constantinople, through the first ecumenical councils, had dictated theology to all Christendom. From the standpoint of the Arabs of Mohammed's time and of the Turks of 1453, Constantinople was not only the capital of a world-empire but the centre and seat of Christianity, the world-religion. Roum (Rome) is the name by which the city of Constantinople was long known among the 
wild tribes of Western Asia. The dread of the Iron Empire was burnt into their souls. To this day the name is not lost, and a Kourd or a Bedouin Arab will often call the Turkish sultan the Sultan of Roum. To those who use the appellation, the sultan is heir to the power and dominion and glory of the Roman Empire, and therefore supreme and terrible in might. After their first attack in 1390 the Turks spent sixty-three years and men and gold without count in five sieges, before the janizaries, pouring through the breach in the triple wall, trampled underfoot the body of the last of the Constantines. Such a triumph outweighed all cost. Through the success of 1453 the influence of Constantinople, for good or evil, passed to Islam, and its leaders thought they had gained a pou sto for upsetting the Christian world.

One would like to form a mental picture of the men into whose hands these advantages fell in 1453. They were mostly Turks not yet really free from the limitations of Central Asia; their descendants, little changed, are still found in the high plains and the mountains of Asiatic Turkey. The Turkish villagers may look upon the stranger from the west as an enemy, for their sphere of vision is still that of the Middle Ages, but their social life is simple, its relations rather pleasing, and its equipment full of reminiscences of the tent. Sturdy, kindly, hardworking men they are, often surprising the traveller by their neighbourly helpfulness. They are strict in attention to their religious duties. If you arrive at a village when the bare-footed crier is announcing the hour of prayer he will not see you, you will have to wait until the prayers are reverently said to the last syllable. The Moslem of Turkey to-day worships the God of the Christian, he will declare that he honours and believes in Jesus Christ, but he cannot stand a theological examination. If he knows how to read at all, the Turkish villager knows no Arabic, and has knowledge of the Koran and of the demands of his religion by hearsay only. Of necessity the notion never enters his mind of a divine purpose to write perfect laws on the hearts of the people for their uplift. If the Turkish villager has an aspiration it is for material well-being of a very simple sort. In 
moral and spiritual and intellectual characteristics he tells you he is as God created him; what is he that he should hope to improve God's handiwork? The sturdy, courageous, common people have been taught by designing leaders to believe that war is a holy service to God, and that the loot of the vanquished is a divinely-appointed reward. This has always ensured their willingness to suffer in endless campaigns for the extension of the faith.

The leaders most relied upon by the sultans for this direction of the minds of the common people have been the Ulema or Doctors of Mohammedan law. In the earlier days of Turkish dominion they were for the most part Arabs. To this day they and the students in their colleges or seminaries are chiefly occupied, a class by themselves, with the writings of the early Arab theologians and experts in Canon Law. They live in an age long gone by, they see all civil affairs from the standpoint of the Koran and its commentators, looking upon the world as divided into two sections-the lands of the peace of Islam, and the lands to be warred upon, and they groan when the sultans find expediency a reason for refusing to declare war on all Europe in the name of religion. The attitude of these bigots towards Christians is shown by the answer of one of them only the other day to the question why Armenians are massacred as a class, when a few only are guilty of treason. The learned divine replied, "When a flea bites you, you kill any flea that you can catch without waiting for proof that he is the one that attacked you."

These men condemn the study of European languages, the reading of European books, interest in European science or European civilisation. So far as their power goes they hold the people to the books that describe eclipses as attempts of a dragon to swallow the sun, and earthquakes as indicating some movement of the tortoise upon whose back the flat earth rests. Their practice within their sphere of influence is accurately described by Lecky's remarks on intellectual life in Europe in the fourteenth century: "The spirit which prevailed had produced a condition of thought in which the very sense of truth seemed blotted out from the 
minds of men. Every mental disposition essential to legitimate research was branded as a sin. It was sinful to study with equal attention and indifferent mind writings on both sides, sinful to resolve to follow the light of evidence wherever it might lead, sinful to remain poised in doubt between conflicting opinions, sinful even to recognise the moral or intellectual excellence of opponents." Having knowledge which is the key to heaven, the Ulema have always exercised strong influence on the sultans, although unable altogether to control them. As for the Moslem common people who know no Arabic, and whom they scornfully term " the vermin underfoot," this learned class at Constantinople has ever aided and rivalled the sultans in exploiting their ignorance. With such religious teachers and such masses of simple, untaught, God-fearing peasants at its command, Islam might use the commanding site of Constantinople for the conquest of a world.

The Turkish sultans could rely upon Asia to supply unlimited numbers of good fighting men, and the city became the base of great operations by land and sea for the enrichment of the sultan and the extension of the faith. Sometimes the armies which it sent forth seemed about to overrun Central Europe. Through two centuries Constantinople was dictator in the Mediterranean and lordly dispenser of Mohammedan doctrine in the borders of Europe. It was not only the fighting hordes of Islam that wrought in Servia, Hungary, Poland, Transylvania and Eastern Austria, to break down the defences and sift the beliefs of Christendom. The stern law of Mohammedan war that refuses quarter until slaughter has terrified a remnant who plead for life, and that makes women and girls wherever found booty to be divided like other chattels, drove the Christian population of all these countries into blind panic at sight of any Turkish horseman. Add to this the peculiarly Turkish practice of sending the half-grown boys of Christian towns and villages to Constantinople to grow into Mohammedan soldiers, and one can almost realise the military power of Islam flung from Constantinople upon Europe in the sixteenth and seventeenth centuries. 
Great multitudes of the people became Mohammedans in all south-eastern Europe. By simply saying, "There is no God but God, and Mohammed is the apostle of God," these wretched people could save their property and their wives and daughters from becoming the spoil of the enemy. Constantinople thus extended the religion of the Arabian prophet from the Adriatic Sea to the Volga. Yet the city was not and is not important to Islam, except incidentally, as a religious centre. Religion has been used to bind many races together; to fire the hearts of ignorant peasants torn from the plough to be soldiers; but it has rarely worked independently of the plans of the astute politicians who built up the Turkish Empire and for a long time it has rarely dominated a sultan. The Sheikh-ul-Islam, or chief interpreter of Canon law in Turkey, is a creation of the sultan, appointed by his decree to secure a foreordained line of policy, or reduced to the ranks when his intellect fails to discover an interpretation of the Koran which seems desirable to his Imperial Master. The same sultan who in 1517 conquered Egypt and the feeble puppet-Caliph, established the rule that the Grand Mufti may not meddle in political affairs.

All these great victories of Islam did not keep Europeans from Constantinople. The city draws men to it by its command of the seas. If Venice was at war with Turkey, Genoa was kneeling before the sultan's throne. If the armies of Islam were doing their pious work in Poland or Austria, France was humbly begging for a treaty of commerce. When a sultan of the sixteenth and seventeenth centuries was in gracious frame he assigned ambassadors lodgings and allotted them rations, as the Emperor of the Universe may condescend to do for representatives of the kinglets whom his clemency has left on their thrones. When the sultan was out of temper he had their secretaries flogged, or locked the whole Embassy in the dungeon of some castle where their memorial scribblings may be read on the prison walls to this day. Constantinople had made Islam a world-power whose assumptions and insults no nation dared hastily resent. Yet the city's need of commercial 
interchange with Europe slowly established illicit but permanent relations between the Moslem state and the misbelievers of the West.

It is now clearly to be seen that this conquered city slowly but necessarily chained the representatives of the Moslem faith in the thraldom of an environment.

Constantinople gave to the Turkish sultans their first glimpses of the civilisation of Christendom. Like the fruit of a forbidden tree this civilisation attracted and gave knowledge of good and evil. Even Mohammed II, the conqueror, made comparisons between his own condition and that of Christian sovereigns. He had been a contented tent-dweller; he found at Constantinople that the Roman emperors had lived in palaces. He approved the idea, built himself a palace on the Byzantine model, and the building of palaces has attracted the attention and the money of Turkish sultans ever since.

One day Mohammed II was sitting with some of his great men in the triclinium of the palace, when a rough soldier-countryman came in, and looking with fearless eyes upon the group asked, "Which of you fellows is the Sultan?" The incident led the attendants to call attention to the advantages of rules of etiquette like those of the Byzantine court. Byzantine rules of court life were promptly introduced. Officials of the court were appointed whose titles and duties were translated and copied from the Greek. The splendid uniforms of the Byzantine Imperial Varangian guard were among the spoils of conquest. Straightway the sultan had a bodyguard in like gorgeous apparel. This splendid uniform, even to its silver halberts, remained the type for the sultan's bodyguard during 400 years. Only about the middle of the nineteenth century did Abdul Aziz abolish it, having learned from European courts that fashions for imperial bodyguards had changed. By such slight infractions of lordly Mohammedan selfsufficiency the seeds of dependence upon Christendom began to grow in Western Islam.

Of course it will not be forgotten that in the early days of this looking to Christendom for material good, 
the Moslems were very far from acknowledgment of such dependence. The conqueror's cannon were cast by the Hungarian Orban before the walls of Constantinople. The great fleet that hemmed in the Byzantine galleys during the siege was commanded by a Bulgarian who abjured Christianity for the sake of this splendid appointment, and took the name of Baltaoglou ("Son of an axe"). Until the nineteenth century almost all the expert artisans, many of the generals and admirals, and some even of the statesmen of Turkey were renegade Christians bought by gold, whose origin is concealed in the histories by the sounding Arabic names which they adopted.

In later times, French, German, and British, and even American experts have been openly employed without the condition of changing their faith, to lay out fortifications, to organise or drill armies, and to build and work a navy. A curious illustration of the extent to which Western Islam has been brought to lean upon Christendom by the capture of Constantinople is found in certain stratifications of the Turkish language. Turkish words signifying the phenomena of the sea, as tides, currents, eddies, etc., as well as names of the species of sea-life are taken bodily from the Greek. Words relating to sailing vessels, their equipment and their manœuvres, are all Italian of the Genoese or Venetian type. As for words relating to steamers, their parts and their manœuvres, the commands of Turkish captains: "Eez. 'er !" "Stap 'er!" " Tarn 'starn ver eezy!" uttered or clumsily written in Arabic characters, betray the English origin of all that the Turks have done in this line.

This habitual tasting the fruits of Christian enterprise, though forbidden by the spirit if not by the letter of the Prophet's doctrines, has had strange results. Anything like a universal war of Islam on Christendom, such as the Prophet commanded and expected, has become physically and perhaps morally impossible. To-day if Christendom were to unite in a boycott that should refuse to sell arms and ammunition and battleships to Turkey, the Caliph of Islam would be "but a noise " like the Pharaoh of Jeremiah's day. 
But what is far more important to the religion of Islam in Constantinople and the regions which it influences, the habit of importing valuable inventions or manufactures from Europe busies an increasing number of Mohammedans with the problem, How do they do it? Not all of them are satisfied as was the Kourd of my acquaintance, who was puzzled to account for the regularity of figures in a piece of chintz, since he had never heard of printing pictures. His spiritual adviser said to him, "Man! Thank God that you are a Moslem. In the lands of the Christians Satan walks in visible form and teaches such tricks to those destined to burn with him in hell." The Moslem who asks the friendly and admiring question, "How do they do it ?" concerning any people outside of Islam is on the way to doubt the present and future supremacy of a system that is bound hand and foot to Arabia and the seventh century.

Constantinople has latterly become the visible centre whence such questionings spring. Some years ago, with a Mohammedan friend, I stood on the lofty tower of the War Department in Constantinople. On the right lay the Sea of Marmora, eastern vestibule of the Mediterranean; on the left the Golden Horn harboured the commerce of all nations ; and beyond the broad span of its mouth was the narrow, winding trough of the Bosporus, ever pouring southward and westward the cold, clear waters of the Black Sea. The high plateaux of Europe on one side and of Asia on the other, dwindled to a level of a few hundred feet, formed steep banks to shut in the blue stream of the Bosporus. One could not fail to realise in that bird's-eye view the thrill with which the Sultan of Turkey, dwelling in its midst, calls himself "Sovereign of the two Continents and Lord of the two Seas." Then said my Mohammedan friend, as if he were a little near-sighted, "One thing is very curious about this view. The greatness and beauty of this city make us all proud. But when one looks upon it from this height one sees a strange contrast between its different quarters. Here, extending far away to the city wall, and there, and there, and there, are great masses of darkcoloured, ragged-looking wooden houses. Surrounded 
by the dark masses, and especially beyond the Golden Horn, in Pera and Galata, are smaller groups of large, well-kept and trim light-coloured houses, often of stone or brick. The contrast makes me as a Mohammedan both puzzled and pained, for the dingy ragged masses of houses mark the Mohammedan quarters of the city, but the bright-looking groups are the houses of the Christians. Why do my people seem less capable than these others?" Possession of this city made possible, to Moslems like my friend, comparisons between Christian ability and Moslem inefficiency. The possession of the City of Two Continents may prove through such comparisons a calamity to Islam.

Every effort of the Mohammedans to live up to the requirements of the city whose renown sprang from the use a Christian Empire had made of it has been in vain. Their institutions have proved a misfit, like their prayerrugs in St. Sophia, which refuse to agree with the ground plan of the Christian cathedral. The religion of Islam has had to become a hampering incident in the political life of Constantinople, instead of being a controlling force in extending its dominion. Notwithstanding the opposition and refusal of the Ulema to participate, and, in fact, to their confusion, Western education was adopted by the Government after the Crimean War as the only means of securing for Moslems prosperity like that seen among their Christian fellow-subjects. Only a few weeks ago a prominent Mohammedan, after a visit to Furope, published in a Turkish paper a strong appeal for reform of the Ulema colleges in Constantinople. He had looked into Christian theological seminaries and had there seen culture in living, practical religion, as well as in the doctrines of the Church. Such culture is altogether absent from the class-rooms where Moslem theological students in Constantinople, year after year, fruitlessly thumb the scholastic ruminations of dead centuries. This growth of intelligence reveals new contrasts. The divorce in Islam between religion and morals shocks thoughtful Moslems, who compare its scandals with the purity and probity seen amorig many Christian business men in the streets of Constantinople. 
An eminent Mohammedan occupying a position of influence in Eastern Turkey once said to me, "My religion requires me to regard you as a blasphemer and an infidel; but $I$ think that God likes this kind of an infidel."

Out of the recent revolutions in Turkey have emerged civil rights for Christians on an equality with Moslems even to seats in Parliament and admission to the army, and, besides these, freedom of the press and of speech for all. These new developments are the fruit of an environment at Constantinople. Intelligent Moslems who have made comparative studies in the history of Western nations discovered that Turkey has been paralysed during centuries by an incubus which can only be thrown off by a free people. Each one of the new measures can be proved by the Ulema to violate teachings of the Koran, each is an attempt to readjust one of the misfits of Islam revealed by the proximity of Christian civilisation. The reformers at Constantinople are Mohammedans, so ardent in devotion that they have this year punished Moslems for public disregard of the outward forms of their religion; but none the less they make their religion subserve political ends. For they know as well as the most fanatical of the Ulema that pan-Islamism can no no longer be a shibboleth when holiness in their military forces is diluted by admixture of unbelievers, and Mohammedanism will cease to be Mohammedanism when the cardinal principle of superiority and universal supremacy has withered away. Islam has proved powerless to control the influence on practical life of Constantinople the cosmopolitan. The City of Two Continents has become to Western Islam a judge that inclines to throw the Canon law out of court as unendurable within sight of Christian practice of equity.

Restoration of absolutism with its remorseless throttling of intellectual life, and in fact restoration of ignorance by an escape from Constantinople with its stimulating and subversive influences, seems the only means of restoring to Turkey the pure, uncompromising Islam. Sultan Abd-ul-Hamid more than once contemplated removing his court to an Asiatic city; but his day has 
passed. The Western Islam will remain for good or for ill under the thraldom of Constantinople the unconquered.

There is a suggestion here for our missions. The strength of Islam lies in ignoranse. The hope of permanence in the work of improvement in Western Islam (in which Christian missions have had a noteworthy share) rests upon breaking down the barriers of ignorance. Young Turks and missionaries join interests at this point. Let the people know, and they can appreciate what is better than all they have yet known. Men who know the Jesus described in the Koran are often moved by real knowledge of His character. Men who see Christians normally acting out the teachings of Jesus, are always quick to say "These men are like angels," and also to follow cautiously in their steps. Even the patiently courteous regard shown by Christians to strangers has profound missionary value when observed and tested by those whose sacred book sets up sectarian hate as a duty and revenge as a choice manly virtue. Every kindly method of showing Moslems what Christianity really is in devotion to God and helpfulness to men will weigh for Christ in the hearts of these wellmeaning people who already profess to revere Him. The great numbers of Bibles sent out from Constantinople through Western Asia and in secret use among Mohammedans have prepared the way for effective objectlessons in Christianity. Perhaps the last of the advantages which Islam can gain from Constantinople may be a will to slough off its scales of moral blindness so as to become what it now is in name-Submission to God.

Nero York.

Henry O. Dwight. 